\title{
Tailored nanocarriers and bioconjugates for combating glioblastoma and other brain tumors
}

\author{
Fatema ELAmrawy', Amr A. Othman ${ }^{1}$, Chris Adkins², Aliaa Helmy ${ }^{1}$, Mohamed I. Nounou ${ }^{1,3}$ \\ ${ }^{1}$ Department of Pharmaceutics and Pharmaceutical Sciences, Faculty of Pharmacy, Alexandria University, Alexandria 21521, Egypt. \\ ${ }^{2}$ Department of Basic Pharmaceutical Sciences, Health Sciences Center, School of Pharmacy, West Virginia University, Morgantown, WV 26506, USA. \\ ${ }^{3}$ Department of Pharmaceutical Sciences, Appalachian College of Pharmacy, Oakwood, VA 24631, USA.
}

Correspondence to: Dr. Mohamed I. Nounou, Department of Pharmaceutical Sciences, Appalachian College of Pharmacy, Oakwood, VA 24631, USA. E-mail:nounou@acp.edu

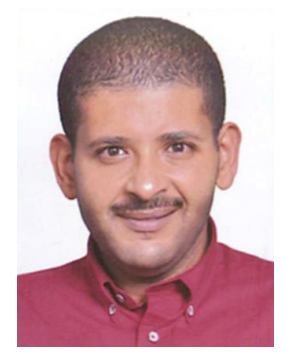

Dr. Mohamed I. Nounou serves the Appalachian College of Pharmacy (Oakwood, VA, USA) as an assistant professor of pharmaceutical sciences. His current research is focused on brain drug delivery, non-viral gene delivery, weight loss management, topical and transdermal drug delivery and quality of pharmaceuticals, nutraceuticals and cosmeceuticals.

\begin{abstract}
Worldwide, the incidence of primary brain tumors is on the rise. Unfortunately, noninvasive drug therapy is hampered by poor access of most drugs to the brain due to the insurmountable blood-brain barrier (BBB). Nanotechnology holds great promise for noninvasive therapy of severe brain diseases. Furthermore, recent bioconjugation strategies have enabled the invasion of the BBB via tailored-designed bioconjugates either with targeting moieties or alterations in the physicochemical and/or the pharmacokinetic parameters of central nervous system (CNS) active pharmaceutical ingredients. Multifunctional systems and new entities are being developed to target brain cells and tumor cells to resist the progression of brain tumors. Direct conjugation of an FDA-approved drug with a targeting moiety, diagnostic moiety, or pharmacokinetic-modifying moiety represents another current approach in combating brain tumors and metastases. Finally, genetic engineering, stem cells, and vaccinations are innovative nontraditional approaches described in different patents for the management of brain tumors and metastases. This review summarizes the recent technologies and patent applications in the past five years for the noninvasive treatment of glioblastoma and other brain tumors. Till now, there has been no optimal strategy to deliver therapeutic agents to the CNS for the treatment of brain tumors and metastases. Intensive research efforts are ongoing to bring novel CNS delivery systems to potential clinical application.
\end{abstract}

Key words: Glioblastoma; brain delivery; blood-brain barrier; nanotechnology; novel treatment

\section{INTRODUCTION}

The central nervous system (CNS) was first described in the Edwin Smith papyrus about 3,600 years ago. ${ }^{[1,2]}$ Tumors and cancer were described in this papyrus, as well as in the Ebers papyrus, dating back to $1,300 \mathrm{BC} \cdot{ }^{[1-3]}$ Hippocrates, the father of Western Medicine, was the first to use the terminology

\begin{tabular}{|l|l|}
\hline \multicolumn{3}{|c|}{ Access this article online } \\
\hline Quick Response Code: & Website: \\
\hline & www.jcmtjournal.com \\
\cline { 2 - 2 } & \\
\hline
\end{tabular}

"karkinos," a Greek word for "crab/cancer," because he noted that these tumors had tentacles reminiscent of the legs of a crab. ${ }^{[4]}$

According to GLOBOCAN 2012, the number of new cases diagnosed with brain tumors were 256,000 for both sexes, out of 14.1 million total cancer cases. ${ }^{[5]}$ The incidence of brain tumors is higher in men than in women. ${ }^{[5]}$ The highest incidence rates

This is an open access article distributed under the terms of the Creative Commons Attribution-NonCommercial-ShareAlike 3.0 License, which allows others to remix, tweak, and build upon the work non-commercially, as long as the author is credited and the new creations are licensed under the identical terms.

For reprints contact: service@oaepublish.com

How to cite this article: ELAmrawy F, Othman A, Adkins C, Helmy $A$, Nounou M. Tailored nanocarriers and bioconjugates for combating glioblastoma and other brain tumors. J Cancer Metastasis Treat 2016;2:112-22.

Received: 17-10-2015; Accepted: 15-12-2015. 


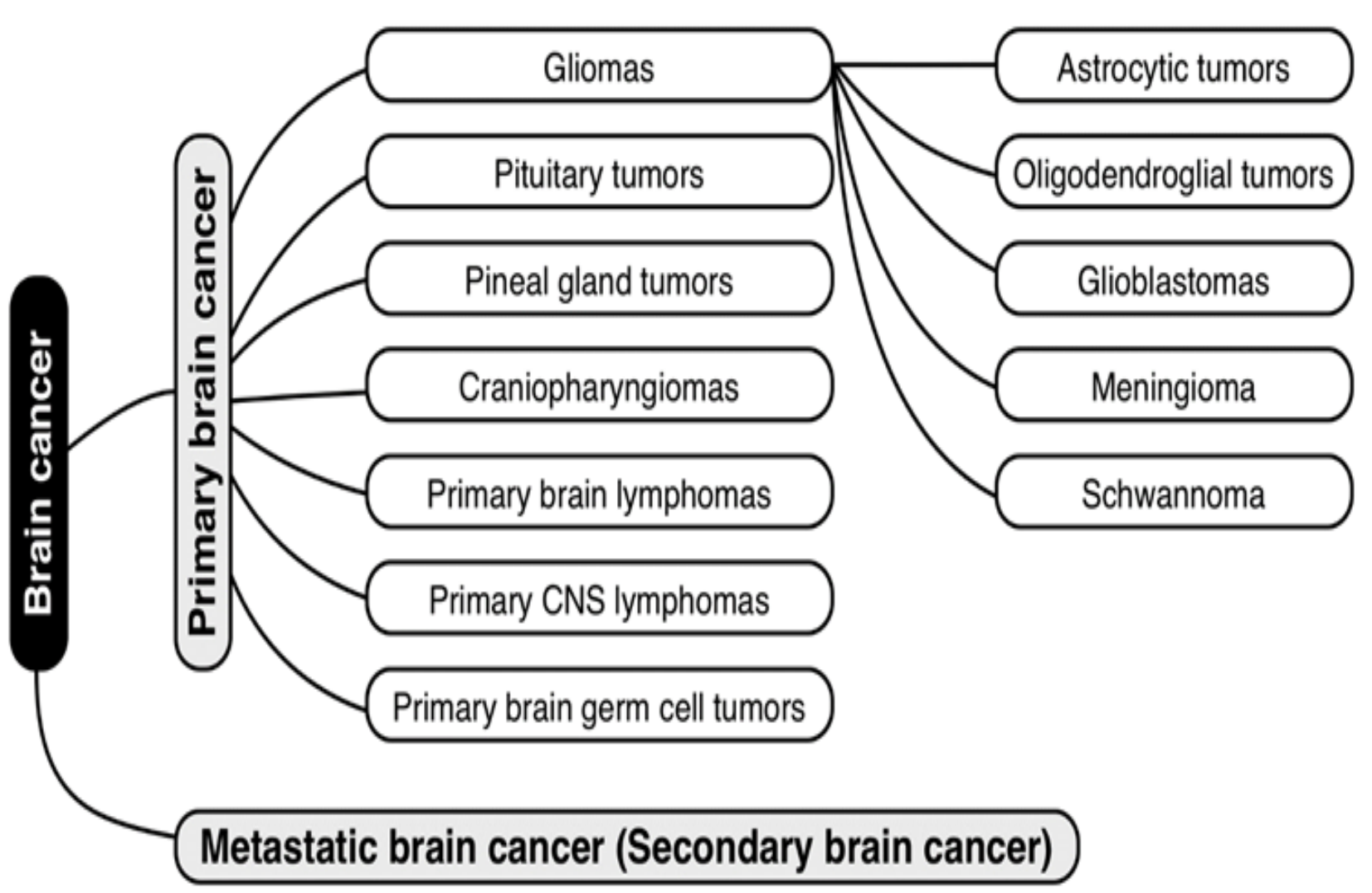

Figure 1: Most common types of brain tumors ${ }^{[6-8]}$

occur in people between 65 and 79 years of age..$^{[5]}$

This review provides an overview of the management of primary brain tumors, especially glioblastoma multiforme. The huge surge in the development of novel strategies for management of primary brain tumors in the past 5 years will be demonstrated in this review article via recent published patents. Table 1 enumerates patents on brain drug delivery and treatment of brain tumors between 2010 and 2015 [supplement material Table 1]. This part of the review will focus on recent patents and studies using nanoparticles and bioconjugates in brain tumor treatment and diagnosis.

\section{TYPES OF BRAIN TUMORS}

Primary brain tumors originate within brain tissue. They are classified according to the type of originating tissue [Figure 1]. The most common primary brain tumors are gliomas, pituitary adenomas, and vestibular and primitive neuroectodermal tumors. ${ }^{[6,7]}$ Gliomas are tumors that begin in the glial tissue. Gliomas include glioblastomas, astrocytomas, schwannomas, oligodendrogliomas, and others. ${ }^{[8]}$

The most common malignant brain tumor is glioblastoma multiforme (GBM, $81 \%$ of malignant CNS tumors), which is usually associated with poor prognosis. ${ }^{[9-11]}$ GBM is classified as a subtype of astrocytoma. GBM is classified as grade IV/V according to the WHO ${ }^{[11]}$ With regard to treatment, GBM and grade III brain tumors are managed similarly.

Any intracranial tumor, regardless of the degree of malignancy, can potentially invade or displace critical brain areas, resulting in neurologic compromises. ${ }^{[12]}$ The most common complications are seizures, peritumoral edema, venous thromboembolism, fatigue, and cognitive dysfunction. ${ }^{[11-13]}$

GBM, is usually described in two different clinical forms, primary and secondary. ${ }^{[14]}$ Primary GBM is the most common form (about 95\%); it typically arises de novo, within 3-6 months,

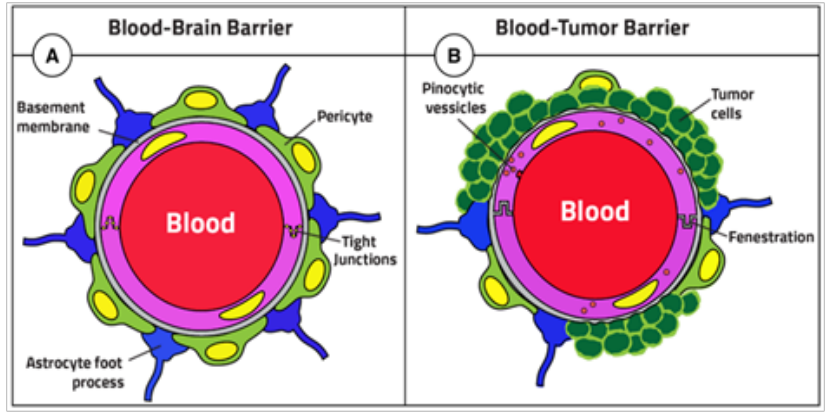

Figure 2: Diagram illustrating the difference between BBB and BBTB. BBB: blood brain barrier; BBTB: blood brain tumor barrier

in older patients. On the other hand, secondary GBM arises from prior low-grade astrocytomas over 10-15 years in younger patients. ${ }^{[13]}$ Both types respond similarly to treatment. ${ }^{[13]}$ 


\section{THE BLOOD-BRAIN BARRIER: THE BRAIN'S PROTECTION SYSTEM}

The blood-brain barrier (BBB) represents a diffusion barrier system that protects the brain. BBB maintains the brain's homeostasis by controlling the influx of blood components into the brain. ${ }^{[15-17]}$ The BBB is mainly formed by brain capillary endothelial cells (BCEC), in addition to other cell types such as pericytes, astrocytes, and neuronal cells that play an important role in its function ${ }^{[17]} \mathrm{BCEC}$ 's tight junction prevents paracellular transport of small and large water-soluble compounds from the circulation to the brain, except for some very small or gaseous molecules such as water and carbon dioxide [Figure 2]. ${ }^{[15,17-20]}$

In addition to physical barriers, several functional barriers contribute to the restrictive nature of $\mathrm{BBB}$, creating major obstacles to effective drug delivery into the CNS. ${ }^{[21]}$ Besides tight junctions, a group of efflux transporters [such as P-glycoprotein (Pgp), breast cancer resistance protein, and multidrug resistanceassociated proteins] are expressed on the brain tissue and collectively cause rapid efflux of large groups of lipophilic drugs from the CNS. ${ }^{[22,23]}$ Also, the presence of numerous degradative enzymes in the BBB creates another functional barrier. ${ }^{[17,24,25]}$

The functioning and organization of the BBB can be altered under pathological conditions, such as in the case of tumors. In such a case, the barrier is called the blood-brain tumor barrier (BBTB). ${ }^{[19]}$ In low-grade gliomas, BBTB resembles $\mathrm{BBB}$, while in high-grade gliomas, BBTB becomes disrupted and "leaky," characterized by major alterations of the normal vascular function manifested by contrast-enhanced MRI by Dhermain et al.${ }^{[19,26]}$ However, the magnitude of this disruption is unlikely sufficient to allow drug penetration in therapeutically meaningful quantities, and thus BBTB remains a major obstacle for brain drug delivery. ${ }^{[27,28]}$

\section{BRAIN DRUG DELIVERY}

Although BBB is difficult to bypass, inventions in the area of brain delivery in the last five years have shown promising progress and well-established techniques. There are two general strategies adopted to facilitate crossing the blood-brain barrier: invasive techniques and noninvasive techniques. ${ }^{[29]}$ Invasive techniques rely primarily on disrupting the BBB's integrity by direct intracranial drug delivery through intracerebroventricular, intracerebral, or intrathecal administration, use of osmotic pumps, or biochemical means. ${ }^{[29]}$ All these approaches are severely limited by poor distribution into brain parenchyma. ${ }^{[30]}$

Noninvasive methods include drug modification through transformation of the drug into lipophilic analogues or prodrugs or through chemical drug delivery, carrier-mediated drug delivery, receptor/vector-mediated drug delivery, and intranasal drug delivery. ${ }^{[29,31]}$ The noninvasive techniques depend on either pharmacologic strategies (lipid-based systems), or physiologic-based strategies (nutrient or receptormediated systems). ${ }^{[31]}$ These techniques will be the focus of the next sections of this review.

\section{Receptor mediated transcytosis}

Receptor-mediated transcytosis facilitates trans-BBB transport of various macromolecules after initial binding of a targeting ligand to a receptor expressed on the brain endothelial cells. ${ }^{[32,33]}$ Transferrin receptor (TfR), insulin receptor, low-density lipoprotein receptor (LDLr), acetylcholine receptor, glutathione transporter, and diphtheria toxin receptor are examples of receptors of interest. ${ }^{[34]}$ Several ligands have been studied and utilized to shuttle nanoparticles, antibodies, and drugs across the BBB and into the brain cells. ${ }^{[35]}$ For instance, the LDL receptor family can be targeted via aprotinin, ApoE3 mimetic, angiopep-2, and p97 (melanotransferrin). ${ }^{[36-38]}$

Angiopep-2, a 19-amino-acid peptide, is one of the promising vectors designed to target the LDLr-related protein to mediate transcytosis across the BBB. ${ }^{[39]}$ Angiochem Inc., in partnership with Geron Inc., developed ANG1005 (also known as GRN 1005), an Angiopep-2-PTX conjugate for treating primary (glioblastoma) and metastatic brain tumors. ANG1005 showed promise in many preclinical studies and was well tolerated in phase I clinical studies. ${ }^{[32,40]}$ However, phase II clinical trials utilizing ANG1005 are either terminated or ongoing but not actively recruiting participants, and Geron has announced that it discontinued development of GRN1005 (NCT014880583, NCT01967810, NCT02048059). ${ }^{[41]}$ Other Angiopep drug conjugates include ANG1007 (angiopep-2-doxorubicin), ${ }^{[42]}$ ANG1009 (angiopep-2-dimethylglycine etoposide), and ANG4043 (angipep 2-trastuzumab). ANG4043 is a novel brainpenetrant peptide-mAb conjugate that is effective against HER2positive intracranial tumors in mice, an angiopep anti-HER 2 mab conjugate. Applications of angiopep as brain targeting moiety are still under intensive research. ${ }^{[43-47]}$

Pieter Gaillard, in a patent for "to-BBB technologies BV," suggested delivery of drugs to cells and across the bloodbrain barrier by targeting them to endogenous internalizing uptake receptors for glutathione on the capillaries of the brain, without modifying or disrupting the normal function of the neuroprotective $\mathrm{BBB}{ }^{[48]}$ In another set of patents, Gaillard and his to-BBB technologies BV group used diphtheria toxin receptor ligand to control the blood-brain barrier vascular permeability and deliver lipopolysaccharide-sensitive nucleic acids and polypeptides across the BBB. ${ }^{[49,50]}$

Dickerson et al ${ }^{[51]}$ developed agents that modulate calcitoningene related peptide (CGRP) signaling. This represents a novel target for cancer, particularly glioma and breast cancer, since CGRP stimulates cell replication and growth. In another patent, Furness et al. ${ }^{[52]}$ invented a method for detecting calcitonin receptor in brain cells of the subject; this method can be used for therapeutic, diagnostic, and prognostic purposes.

Due to the increased expression of the transferrin receptor in brain glioma, it is one of the most extensively studied targets for receptor-mediated transcytosis (RMT). ${ }^{[53]}$ Cedars-Sinai 
Medical Center owned two patents on using anti-TfR antibodies conjugated to polycefin-LLL to cross $\mathrm{BBB} \cdot{ }^{[54]}$ In the second patent, Patil et al. ${ }^{[55]}$ prepared polycefin-LLL nanonjugates that could be loaded with temozolomide (TMZ) in its hydrazide form and modified with PEG.

A promising approach to enhance brain delivery is to inhibit efflux transporters by modulating their expression and/or activity. ${ }^{[56,57]}$ Clinical trial data of third-generation inhibitors (ariquidar, zosuquidar and elacridar) are awaited for possible clinical application of this treatment approach. ${ }^{[58]}$ Other naturally occurring compounds such as curcumin, ${ }^{[59]}$ quercetin, ${ }^{[60,61]}$ and kaempferol are being studied and modified for use in brain cancer therapy to overcome the problem of multidrug resistance (MDR) ${ }^{[62]}$ Barthomeuf et al. ${ }^{[22]}$ studied the use of curcuminoid compounds to enhance the clinical efficacy of docetaxel for the treatment of cancers including GBM. The group proposes that, in addition to reducing Pgp transport, curcumin may reduce HIF-1dependent and HIF-1-independent angiogenesis, which in turn would inhibit tumor progression, angiogenesis, and induction of resistance. ${ }^{[22]}$ Banks et al ${ }^{\left[{ }^{[3]}\right]}$ provided a method to inhibit the function of RNA- and DNA-encoding efflux transporters among other blood-brain barrier proteins using antisense compounds. The patent suggests that inhibition of Pgp expression would allow increased accumulation of chemotherapeutic drugs in the $\mathrm{CNS}$ and thus improve therapeutic clinical outcomes.In another patent, McChesney et al. used a group of taxane analogues that stabilize tubulin dimers or microtubules at G2-M during mitosis but are not substrates for MDR proteins. ${ }^{[64]}$

The physiologic approach to target brain tumors takes advantage of endogenous receptors that are highly expressed at the BBB. ${ }^{[30,31]}$ Unfortunately, almost all the receptors are nearly nonspecific as indicated by percentage dose reaching the brain following administration compared to percentage reaching other organs such as the liver, spleen or lung. ${ }^{[30]}$ To avoid such nonselective patterns, Tosi et al..$^{[65]}$ used double-targeting ligands to provide added targeting benefit and minimize nonselectivity. The targeting ligands used by Tosi et al. ${ }^{[65]}$ were sialic acid and glycopeptides. The targeting ligands were covalently conjugated to PLGA nanoparticles (SA-g7-Np). ${ }^{[65]}$

\section{Nanocarriers for brain drug delivery}

Nano-based delivery systems have seized increased attention from formulators, as indicated by recent patents and studies[ supplement material Table 1]. This can be attributed to their unique ability to deliver to therapeutic and diagnostic moieties. ${ }^{[66-72]}$ Nanocarriers are unique because of their small size (typically sub $200 \mathrm{~nm}) \cdot{ }^{[73]}$ Nanoparticles are easily tailored in their structure and properties. ${ }^{[73]}$ They also can carry active therapeutic or diagnostic moieties of heterogeneous physicochemical properties, and their release pattern can be controlled. ${ }^{[73]}$

A representation of possible NP structure(s) is shown in Figure 3A. NPs can be formulated from different materials including polymers, lipids, organometallic compounds, and viruses. ${ }^{[74]}$
However, mostly amphiphilic molecule-formed liposomes and polymeric nanoparticles (chemical species having a "polar" head group and "hydrophobic" tails) have been extensively exploited for brain drug delivery. ${ }^{[73,75]}$ Long circulation time of the delivery system can be achieved by conjugating the nanoparticles with polyethylene glycol (PEG) ("PEGylation"). ${ }^{[66,67]}$ The PEGcoated nanoparticles can escape the mononuclear phagocytic system and circulate in the body for a longer time, increasing the chance of reaching the target and thereby enhancing the effect of the loaded drug. ${ }^{[6,67]}$ The effect and benefits of PEGylation are discussed later.

Unfortunately, nanoparticles can carry some serious adverse effects. ${ }^{[76]}$ Adverse effects of nanoparticles depend on individual factors such as genetics, existing disease conditions, exposure, nanoparticle chemistry, size, shape, agglomeration state, and electromagnetic properties. ${ }^{[76]}$ The key to understanding the toxicity of nanoparticles is their size. ${ }^{[76]}$ Nanoparticles are smaller than mammalian cells and cellular organelles, which allows them to penetrate these biological structures and disrupt their normal function. ${ }^{[76]}$ Examples of toxic effects include tissue inflammation and altered cellular redox balance toward oxidation, causing abnormal function or cell death. ${ }^{[76]}$

\section{Polymeric nanoparticles}

Polymeric micelles are formed from amphiphilic block copolymers forming a core/shell nanostructure. In aqueous media, the hydrophilic heads are arranged to the outside and the hydrophobic tails to the inside to stabilize the structure, which is suitable for IV injections ${ }^{[77]}$. Delivery of docetaxel for the treatment of brain tumors by cyclic arginine-glycine-aspartic acid (RGD)-tagged polymeric micelles was developed by Li et $a l .{ }^{[78]}$ The authors found that RGD has affinity to bind to integrin receptor, which is overexpressed in glioblastoma tissues. ${ }^{[78]}$

Krebs invented a novel biodegradable hydrogel polymer comprising chitin and poly(lactic-co-glycolic acid) for delivery of therapeutic agents to brain tumors. ${ }^{[79]}$ The biodegradable hydrogel detailed in Krebs' patent would allow release of antiVEGF to the periphery of the resected tumor site in a localized manner, with stable release rate over a sustained period. The $\mathrm{pH}$-sensitive polymers which release the drug in an acidic microenvironment of solid tumors and endosomes, were the focus of a patent by Bae et al. ${ }^{[80]}$ Targeting ligands, such as folate, can also be attached to the mixed micelles for enhancing drug delivery into brain cells. ${ }^{[56]}$

Zhou et al. ${ }^{[81]}$ in a recent patent, developed small, less aggregable brain-penetrating polymeric nanoparticles that can be loaded with drugs. In another patent, Wu et al..$^{[82]}$ used polymethacrylic acid grafted starch (PMAA-g-St) nanoparticles containing polysorbate moieties that can target the polymer to brain tissues. Hyper-branched polymer of polyglycerol-amine (PG-NH2) was demonstrated to accumulate in the tumor environment due to the enhanced permeability and retention effect (EPR), as described in a patent by Yerushalmi et al..$^{[83]}$ 
Tour et $a l .{ }^{[84]}$ devised poly(ethylene glycolated) Hydrophilic Carbon Clusters Antibody Drug Enhancement System (HADES), in which nanovectors are coupled with an active agent and one of the agents that target glioma surface antigens, such as Interleukin 13 receptor (IL-13R), epidermal growth factor receptor (EGFR), and Gglial fibrillary acidic protein (GFAP).

\section{Lipid-based nanoparticles}

Liposomes are the first generation of nanoparticulate drug delivery systems and consist of one or more vesicular bilayers (lamellae) composed of amphiphilic lipids, delimiting an internal aqueous compartment. ${ }^{[85]}$ The most advantageous features of liposomes are their ability to incorporate and deliver large amounts of drugs and the possibility of decorating their surface with various ligands. ${ }^{[86]}$

Chlorotoxin-modified, doxorubicin-loaded liposomes were described by Xiang et al ${ }^{[87]}$ to target chloride channel-mediated brain gliomas. Also, Li et al. ${ }^{[88]}$ suggested that chemotherapy using functional targeting of paclitaxel via artemether liposomes could provide a novel strategy for treating invasive brain glioma. Chen et al. ${ }^{[89]}$ studied lactoferrin-modified, doxorubicin-loaded procationic liposomes and showed that the system offers effective therapeutic potential for gliomas. Cationic liposomes were described in a patent by Migliore et al.$^{[90]}$ to provide a novel, noninvasive strategy for nasal delivery of neuroactive proteins to the brain for treatment of central nervous system disorders. In another patent by Munson et al. ${ }^{[91]}$ PEGylated uni-lamellar vesicle liposomes were described that were appropriately sized and formulated to cross the blood-brain barrier to deliver imipramine. To overcome toxicity associated with high peak drug concentration, Redelmeierand Luz used a non-PEGylated liposomal composition comprising at least one saturated neutral phospholipid and at least one saturated anionic phospholipid encapsulating a therapeutic or diagnostic agent. ${ }^{[92]}$

\section{Solid lipid nanoparticles}

Solid lipid nanoparticles(SLN) are stable lipid-based nanocarriers with a solid hydrophobic lipid core in which the drug can be dissolved or dispersed. ${ }^{[93,94]}$ They are made of biocompatible lipids such as triglycerides, fatty acids, or waxes. ${ }^{[33,94]}$

Nanoparticles containing brain-derived lipids may be transported into the brain via specific receptors for these lipids. Panyamand Chavanpatil designed nanoparticles composed of a brain lipid (phospholipid), a supplemental lipid (long chain saturated or unsaturated fatty acids, stearic acid, palmitic acid, linolic acid, or linoleic acid) and a PEG-conjugated lipid (dist earoylphosphatidylethanolamine-polyethylene glycol). ${ }^{[95]}$ This nanoparticle system can deliver a drug or therapeutic compound to the brain. ${ }^{[95]}$

Jin et al.${ }^{[96]}$ used solid lipid nanoparticles made of lipids extracted from deproteinated lipoproteins and enriched with cationic cholesteryl hydrochloride and phosphatidyl-ethanolamine. The authors, after intravenous administration of such cationic NPs for the delivery of siRNA to inhibit c-Met expression, were able to suppress the tumor growth without evident signs of systemic toxicity in an orthotopic xenograft tumor mouse model of glioblastoma. ${ }^{[96]}$

Singh et $a l .{ }^{[97]}$ studied lactoferrin-bioconjugated solid lipid nanoparticles as a new drug delivery system for potential brain targeting. Lactoferrin was conjugated to the surface of SLN using carbodimide coupling. SLN surface-conjugated with lactoferrin-encapsulating docetaxel maintained its complete activity and conserved its mechanism of action as characterized by cell viability and apoptosis studies. ${ }^{[97]}$

\section{PEGylated-liposomal formulation for enhanced pharmacokinetics (Stealth ${ }^{\circledR}$ technology)}

PEGylated liposomal doxorubicin (PLD; Caelyx ${ }^{\mathrm{TM}}$, Doxil ${ }^{\circledR}$ ) represents the first commercial liposomal formulation for passive cancer management with enhanced efficacy and reduced toxicity profile. ${ }^{[98]}$ PLD is superior to the conventional doxorubicin preparation, showing reduced cardiotoxicity and prolonged activity due to stealth properties imparted by its polyethylene glycol PEG layer. Despite PLD smart passive properties in targeting cancer, its long circulation half-life and its ability to escape the reticuloendothelial system (RES) defense mechanism, it fails to manage brain tumors because of the BBB enhanced protective features. ${ }^{[50]}$

For the PLD to cross BBB, glutathione-PEGylated liposomal doxorubicin (2B3-101) is being investigated. Based on the patent owned by BBB Therapeutics BV (formerly, to-BBB technologies), glutathione-based drug delivery system can target brain tissues by receptor-mediated transcytosis. ${ }^{[50]}$ According to the preclinical studies, 2B3-101 showed a 5-fold enhanced doxorubicin brain delivery versus PLD (Doxil $\left.{ }^{\circledR}\right) .{ }^{[99]}$ The company held a phase I/IIa clinical study in patients with solid tumors and brain metastases or recurrent malignant glioma. ${ }^{[100]}$

Nektar develops new drug candidates by utilizing its proprietary 3D 4-armed branched PEGylation and advanced polymer conjugate technologies to modify the chemical structure of various active pharmaceutical ingredients. It is a PEGylation technology supplier to a number of pharmaceutical companies including Affymax Inc., Amegen Inc., Merck and Co. Inc., Pfizer Inc., and UCB Pharma. ${ }^{[101]}$ Nektar Therapeutics is currently investigating the use of etirinotecan pegol (NKTR-102) for treating brain tumors. ${ }^{[101,102]}$ Furthermore, Nektar Therapeutics is conducting a phase II pilot study of NKTR-102 in patients with recurrence of high-grade glioma after bevacizumab therapy. ${ }^{[102]}$

\section{Bioconjugates delivery systems}

The main aim of bioconjugation is to form a stable, biologically cleavable covalent link between two molecules, at least one of which is a biomolecule [Figure 3B]. ${ }^{[103]}$ Bioconjugation is a form of functionalization of nanoparticles, which aims to increase stability, protect a drug from proteolysis, or enhance the targeting properties of the delivery system. ${ }^{[77,103]}$ In spite of the historic fact that bioconjugates are older than nanoparticles, 
research is increasingly being diverted back to it. ${ }^{[103]}$ Factors that may encourage this resurgence of interest could include its ease of synthesis, high scale-up yield, ease of bench-to-bedside transformation, ease of formulation, and final formulation stability ${ }^{[103]}$ Bioconjugation reactions are generally categorized by the general reactivity or the functional group involved in the conjugation process, such as amine reactions, thiol reactions, carboxylate reactions, hydroxyl reactions, aldehyde and ketone reactions, active hydrogen reactions, photochemical reactions, and cyclo-addition reactions. ${ }^{[103]}$ The design of a useful bioconjugate will depend mainly on its use, purpose, and the desired properties needed. ${ }^{[104]}$ Thus, one could choose a suitable molecule and a proper cross-linker to form the bioconjugate. ${ }^{[104]}$ The key to forming a successful bioconjugate is choosing the suitable crosslinker between the molecules. ${ }^{[103]}$

As in any delivery system, bioconjugates are usually tailordesigned to provide the function of interest. The active drug entity can be linked to a diagnostic agent, targeting moiety, pharmacokinetics-modifying agent such as PEG, bioresponsive or stimuli-sensitive agent, an aptamer, or an antibody. Furthermore, the choice of the proper linker can impart new functions and smart characteristics to the bioconjugate system [Figure 3].

A bioconjugate was patented by Bacha et al. ${ }^{[105]}$ that may compromise a chimeric peptide of the structure of Formula (D-III): A-NH( $\left(\mathrm{CH}_{2}\right)_{2} \mathrm{~S}-\mathrm{S}-\mathrm{B}$ (cleavable linkage), avidin-biotinagent complex, PEG layer, and a fusion protein for targeting the brain tumor. Another bioconjugate formulation, developed by Jefferies et al..$^{[38]}$ comprised a BBB-transport moiety linked to an antibody or therapeutic Fc-fusion polypeptide. Jefferies et $a l{ }^{[38]}$ modified $\mathrm{Fc}$ regions to facilitate the delivery of therapeutic and/or diagnostic polypeptides across the BBB and thereby treat and/or diagnose conditions associated with the CNS, including cancer.

A patent entitled "Anti-EGFR antibody drug conjugate formulations" by Tschoepe et al. ${ }^{[106]}$ discussed a staple formulation including: an anti-EGFR antibody or antigenbinding portion thereof conjugated to an auristatin, a sugar,

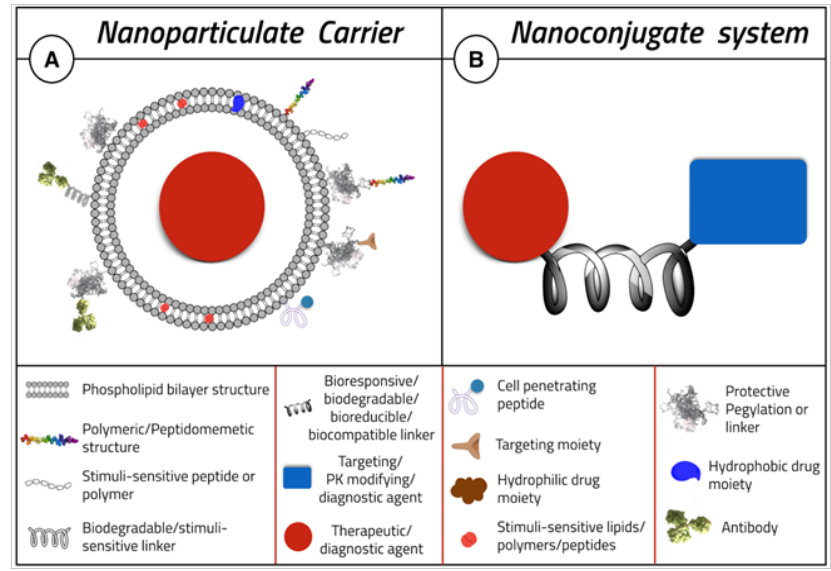

Figure 3: Diagrammatic sketch for nanoparticulate and nanoconjugate systems design strategies a surfactant, and histidine. In their patent Adair et al. ${ }^{[107]}$ described nonaggregating resorbable calcium phosphosilicate nanoparticles bioconjugated to targeting molecules that are specific for brain cells. The targeting moieties used by Adair et $a l .{ }^{[107]}$ included antibodies, peptides, ligands, and/or receptors having sulfhydryl-group. Hutchison invented p97-antibody conjugates and related compositions that could be used in the treatment of cancers such as Her2/neu-expressing and Her1/ EGFR-expressing cancers to inhibit, prevent, or delay the metastasis of an antibody-resistant cancer. ${ }^{[108]}$

Kang et al. ${ }^{[109]}$ hypothesized that modification of calreticulin (CRT) peptide to poly(ethylene glycol)-poly(l-lactic-co-glycolic acid) (PEG-PLGA) nanoparticles would mediate drug transport across the $\mathrm{BBB}$ and enable deep penetration to the interior of the glioma by functionally mimicking iron. Their study proved that CRT-NP significantly improved the therapeutic efficacy of paclitaxel for the treatment of gliomas. ${ }^{[109]}$

\section{Toxins: targeting agents and a potential treatment}

Disintegrins, a group of snake venom toxins, have the potential to block cancer cell migration and invasion by interaction with integrins. ${ }^{[110]}$ Contortrostatin, a snake venom disintegrin, was proven to inhibit tumor growth and angiogenesis and to prolong survival in a rodent glioma model by Pyrko et $a l . .^{[111]}$ Similarly, scorpion venoms has been used in targeting brain tumors, in tumor painting, and in cell sensitization to chemotherapy ${ }^{[112-114]}$ Chlorotoxin (CTX) is a promising tool for glioma management. ${ }^{[112,115-118]}$

Chlorotoxin binds to metallomatrix proteins-2 and a gliomaspecific chloride channel. ${ }^{[119]} \mathrm{CTX}$ is a highly diffusible peptide that can cross the BBB or the BBTB with, to date, no evident signs of toxicity for normal human cells. ${ }^{[10]}$ Coated iron superoxide particles conjugated to CTX may be used as a MRI contrast agent as well as for delivering therapeutic agents (e.g. O6-benzylguanine and siRNA) to glioma cells. ${ }^{[120-122]}$ Other toxins such as BLZ-100 are being investigated. ${ }^{[123,124]}$

\section{Physically facilitated brain drug-delivery}

Advanced physically manipulated systems can be used to treat diseases and allow controlled dosage of drugs. Physical manipulation can be achieved via ultrasound, electric, magnetic, or photonic-emission technologies. ${ }^{[125]}$ Davalos et al. ${ }^{[126]}$ applied pulsed electric fields into brain tissue of an animal to cause temporary disruption of the BBB. There are examples of using electromagnetic field pulses to induce the permeability of the BBB. Qiu et al.$^{[127]}$ showed that electromagnetic pulses alter $\mathrm{BBB}$ permeability via regulating protein kinase $\mathrm{C}$ signaling and translocation of tight junction's protein ZO-1.

Kievit et al ${ }^{[122]}$ attached chlorotoxin to an iron oxide magnetic nanoparticle (MNP) core using a short PEG linker. Similarly, in vivo experiments by Braun et al. ${ }^{[128]}$ have shown the effects of MNPs within a magnetic field on glioma cells lasting up to 100 min postexposure. A patent by Akhtari and Engel used functionalized MNP that comprise a moiety that provides 
selective association with cancer cells for the treatment and diagnosis of brain tumors. ${ }^{[129]}$

Yang and David formulated magnetic iron oxide nanoparticles (MIONs) coated with a molecule that is noncovalently associated with a brain-targeting molecule. The coated MIONs comprise an anti-tumor agent linked to a cell-penetrating peptide. ${ }^{[130]}$ MIONs are oriented at the site of the brain tumor with an external magnetic field. ${ }^{[130]}$ In a patent by Dixit et al. ${ }^{[131]}$ gold nanoparticles conjugated with peptides against both EGFR and TfR and loaded with the photosensitizer phthalocyanine 4 have been designed and characterized. Laser was then applied to activate the photosensitizer, causing subsequent cell death. ${ }^{[131]}$

On the other hand, nonthermal techniques to reversibly open BBB have been studied. One of these techniques is using ultrasound in the presence of microbubbles (MB). ${ }^{[132,133]} \mathrm{MB}$ work by resonating in an ultrasound beam, rapidly contracting and expanding in response to the pressure changes of the sound wave. ${ }^{[134]}$ Inertial cavitation and destruction of microbubbles are capable of producing strong mechanical stress to enhance the permeability of the surrounding tissues and further increase the extravasation of drugs into the cytoplasm or interstitial cells. ${ }^{[135]}$ Chen et al. ${ }^{[136]}$ studied MB-carrying TGF $\beta 1$ inhibitor combined with ultrasound sonication to induce BBB/BTB disruption and enhance drug delivery. Pulsed-mode ultrasound exposure therapy was recently shown to enhance the antitumor effect of an EGFR-targeting chemotherapeutic drug facilitating antiglioma treatment. ${ }^{[137]}$

\section{NUCLEIC ACID TECHNOLOGIES}

\section{MicroRNA}

MicroRNAs (miRNAs) are endogenous RNAs composed of about 22 nucleotides. The miRNAs can play important regulatory roles in animals and plants by targeting mRNAs for cleavage or translational repression. ${ }^{[138,139]}$ Currently, about $2 \%$ of known human genes encode microRNAs. ${ }^{[140]}$ A growing body of evidence shows that miRNAs are one of the key players in cell differentiation and growth, mobility, and apoptosis. ${ }^{[141-143]}$ Most microRNAs in animals are thought to function by inhibition of effective mRNA translation of target genes through imperfect base pairing with the 3-untranslated region of target mRNAs. ${ }^{[138,140]}$

MiRNAs are appealing therapeutic targets and potential biomarkers of GBMs. ${ }^{[141-143]}$ Chan et al. ${ }^{[144]}$ were the first to investigate the functional properties of a single miRNA in GBM cell lines. They discovered that high expression of miR-21 is a common feature of GBM. ${ }^{[144]}$ In GBM, 15 types of miRNAs are the most studied (miR-7, miR-10b, miR-15b, miR-17, miR-21, miR-23a, miR-25, miR-124, miR-128a, miR-128b, miR-132, miR-137, miR-195, miR-221 and miR-222). ${ }^{[145]}$ In a patent by Park et al. ${ }^{[146]}$ hypoxia-induced angiogenesis-associated diseases including cancers was suggested to be treated by miRNA-125.

\section{Aptamers}

Aptamers are nonbiological oligonucleotides that can bind to protein targets. ${ }^{[147]}$ Aptamers can be used for therapeutic purposes in the same way as monoclonal antibodies. ${ }^{[147]}$ However, unlike traditional methods for producing monoclonal antibodies, no organisms are required for the in vitro selection of oligonucleotides. ${ }^{[147]}$ For this reason, aptamers avoid the immunogenicity of antibodies while maintaining all their properties. $^{[147]}$ However, there still remain largely unknown pharmacokinetic properties which make them harder to develop than any given therapeutic antibody. ${ }^{[147]}$

Aptamers, consisting of a single-stranded nucleic acid having 100 nucleotides or less that specifically bind to tumor-initiating cancer cells, were developed and described by Rich et al ${ }^{[148]}$ The aptamer specifically binds to tumor-initiating cells of GBM. ${ }^{[148]}$ Aptamers were the targeting agent of choice for a patent by Bloembergen et al ${ }^{[149]}$ where they used an aptamer-biopolymeractive agent conjugate system for the treatment of cancer.

\section{CONCLUSIONS AND FUTURE DIRECTIONS}

The development cycle of new therapeutic drug entities for brain and CNS costs from $\$ 500$ million to $\$ 1.5$ billion to get to market. Such huge expense could be directly attributed to drugs failing late in clinical trials or during the post-market follow-up (Phase IV) ${ }^{[150]}$ In spite of the advances in drug discovery technologies and high-throughput screening techniques, the development cycle of new therapeutic entities is still costly and lengthy. It is challenging to ensure efficacy and safety throughout the four phases of clinical trials. ${ }^{[151,152]}$

To overcome these problems and alleviate some of the costs associated with new drug entity letdown, pharmaceutical formulators spend effort modifying and reinventing therapeutic and diagnostic agents, giving them new characteristics with enhanced safety and efficacy profiles. The use of novel nanosized drug delivery systems (nanoDDS) is a major approach in such reinvention process. The nanoDDS can provide methods for targeting and releasing large quantities of therapeutic agents in exact, well-defined organs or tissues. Furthermore, they can easily be tailored, decorated, and modified via various agents such as stimuli-sensitive moieties, targeting agents, pharmacokinetics-modifying mediators, diagnostic agents, cellpenetrating peptides, protective PEGylation layer, or antibodies. Such modifying moieties can provide novel functions and better efficacy or safety profiles to current therapeutic agents. Furthermore, most nanoDDSs provide both hydrophobic and hydrophilic environments, facilitating better drug solubility and enhanced physicochemical characteristics. ${ }^{[153]}$

Despite their advantages, nanoDDS suffer from many problems such as stability issues, formulation scale-up difficulties, and short shelf life. Developing novel complexes and sophisticated systems that could never reach the market due to high cost, inability of scaling-up the system, or instability of the final formulation is a major problem. Major process and formulation development concerns exist with respect to the scale-up process of complex nanoparticulate carriers. To overcome 
these problems, pharmaceutical formulators started to divert their effort from nanoDDS to simple bioconjugate techniques to directly attach old problematic active pharmaceutical agents such as stimuli-sensitive moieties, targeting agents, pharmacokinetics-modifying mediators, diagnostic agents, cellpenetrating peptides, protective PEGylation layer, or antibodies. Active pharmaceutical ingredients can be directly conjugated to antibodies against specific cell-type markers to create a hybrid smart molecule that is able to direct the active molecule to the disease tissue specifically. Consequently, many patents currently focus on simple bioconjugate structuresthat are easily synthesized with high yield, reduced cost, and high stability of the final formulation. This could provide a practical direction for the development of novel management tools and therapeutics for brain cancer for researchers worldwide, paving the road to affordable, scalable, stable, efficient, and safe management strategies.

All such techniques and technologies were illustrated in the recent patents analyses discussing brain drug delivery during 2010 to 2015. Despite such efforts, the development of brain drug delivery carrier system is still costly and troublesome in its transformation from bench to bedside. Such systems require huge effort in their in vivo, in vitro testing and clinical trials. Most of the research funding in academia for brain delivery research comes from investing companies. Most of the companies investing in this field are small startups such as to-BBB and BiOasis Therapeutics. If such industrial startups fail to develop a promising moiety or carrier for brain drug delivery, their existence is usually jeopardized. ${ }^{[154,155]}$ An integrated "benchto-clinic" approach, realized through a structural collaboration between industry and academia, would strongly promote the development of brain tumor-targeted nanomedicines towards effective and safe clinical application. ${ }^{[156]}$

\section{Financial support and sponsorship}

Nil.

\section{Conflicts of interest}

There are no conflicts of interest.

\section{REFERENCE}

1. Jex HS. The Edwin Smith Surgical Papyrus: first milestone in the march of medicine. Merck Rep 1951;60:20-2.

2. Sanchez GM, Meltzer ES. The Edwin Smith Papyrus: Updated translation of the trauma treatise and modern medical commentaries: Lockwood Press;2012.

3. Brayn CP, Smith GE. The Papyrus Ebers, translated from the german version. Letchworth, Herts. The Guardian City Press LTD;1930.

4. Papavramidou N, Papavramidis T, Demetriou T. Ancient Greek and Greco-Roman methods in modern surgical treatment of cancer. Ann Surg Oncol 2010;17:665-7.

5. Ferlay J SI, Ervik M, Dikshit R, Eser S, Mathers C, Rebelo M, Parkin DM, Forman D, Bray F. Globocan 2012, Cancer Incidence and Mortality Worldwide: IARC. In: internet N, editor. Cancer Fact Sheets. Lyon, France: International Agency for Research on Cancer; 2013.

6. Dolecek TA, Propp JM, Stroup NE, Kruchko C. CBTRUS statistical report: primary brain and central nervous system tumors diagnosed in the United States in 2005-2009. Neuro Oncol 2012;14 Suppl 5:v1-49.
7. Ostrom QT, Gittleman H, Farah P, Ondracek A, Chen Y, Wolinsky Y, Stroup NE, Kruchko C, Barnholtz-Sloan JS. CBTRUS statistical report: primary brain and central nervous system tumors diagnosed in the United States in 2006-2010. Neuro Oncol 2013;15 Suppl 2:ii1-56.

8. Molnár Pt. Classification of primary brain tumors: molecular aspects, management of CNS tumors. InTech;2011.

9. Chandana SR, Movva S, Arora M, Singh T. Primary brain tumors in adults. Am Fam Physician 2008;77:1423-30.

10. Parrish KE, Sarkaria JN, Elmquist WF. Improving drug delivery to primary and metastatic brain tumors: Strategies to overcome the bloodbrain barrier. Clin Pharmacol Ther 2015;97:336-46.

11. Alifieris C, Trafalis DT. Glioblastoma multiforme: Pathogenesis and treatment. Pharmacol Ther 2015;152:63-82.

12. Armstrong TS. Head's up on the treatment of malignant glioma patients. Oncol Nurs Forum 2009;36:E232-40.

13. Wen PY, Kesari S. Malignant Gliomas in Adults. $N$ Engl $J$ Med 2008;359:492-507.

14. Kleihues P, Ohgaki H. Primary and secondary glioblastomas: from concept to clinical diagnosis. Neuro Oncol 1999;1:44-51.

15. Ballabh $\mathrm{P}$, Braun A, Nedergaard $\mathrm{M}$. The blood-brain barrier: an overview: structure, regulation, and clinical implications. Neurobiol Dis 2004;16:1-13.

16. Cook LJ, Freedman J. Brain Tumors. New York: The Rosen Publishing Group; 2012

17. Dauchy S, Miller F, Couraud PO, Weaver RJ, Weksler B, Romero IA, Scherrmann JM, De Waziers I, Decleves X. Expression and transcriptional regulation of $\mathrm{ABC}$ transporters and cytochromes $\mathrm{P} 450$ in hCMEC/D3 human cerebral microvascular endothelial cells. Biochem Pharmacol 2009;77:897-909.

18. Abbott NJ, Friedman A. Overview and introduction: the blood-brain barrier in health and disease. Epilepsia 2012;53:1-6.

19. van Tellingen O, Yetkin-Arik B, de Gooijer MC, Wesseling P, Wurdinger $\mathrm{T}$, de Vries HE. Overcoming the blood-brain tumor barrier for effective glioblastoma treatment. Drug Resist Updat 2015;19:1-12.

20. Hawkins BT, Davis TP. The blood-brain barrier/neurovascular unit in health and disease. Pharmacol Rev 2005;57:173-85.

21. Deeken JF, Loscher W. The blood-brain barrier and cancer: transporters, treatment, and Trojan horses. Clin Cancer Res 2007;13:1663-74.

22. Barthomeuf C, Chollet P, Bayet-Robert M. Curcuminoids in Combination Docetaxel for the Treatment of Cancer and Tumour Metastasis. In: Institut National De La Sante Et De La Recherche Medicale (Inserm); 2014. (ISBN No. US20140128337 A1)

23. Loscher W, Potschka H. Blood-brain barrier active efflux transporters: ATP-binding cassette gene family. NeuroRx 2005;2:86-98.

24. Ghosh C, Gonzalez-Martinez J, Hossain M, Cucullo L, Fazio V, Janigro D, Marchi N. Pattern of P450 expression at the human blood-brain barrier: Roles of epileptic condition and laminar flow. Epilepsia 2010;51:1408-17.

25. Minn A, Ghersi-Egea JF, Perrin R, Leininger B, Siest G. Drug metabolizing enzymes in the brain and cerebral microvessels. Brain Res Brain Res Rev 1991;16:65-82

26. Dhermain FG, Hau P, Lanfermann H, Jacobs AH, van den Bent MJ. Advanced MRI and PET imaging for assessment of treatment response in patients with gliomas. Lancet Neurol2010;9:906-20.

27. Tzeng SY, Green JJ. Therapeutic nanomedicine for brain cancer. Ther Deliv 2013;4:10.4155/tde.13.38.

28. Madsen SJ, Hirschberg H. Site-specific opening of the blood-brain barrier. J Biophotonics 2010;3:356-67.

29. Kazantsev AG, Outeiro TF. Drug discovery for CNS disorders: from bench to bedside. CNS Neurol Disord Drug Targets 2010;9:668.

30. Gabathuler R. Approaches to transport therapeutic drugs across the bloodbrain barrier to treat brain diseases. Neurobiol Dis 2010;37:48-57.

31. Pardridge WM. Drug delivery to the brain. J Cereb Blood Flow Metab 1997;17:713-31.

32. Drappatz J, Brenner A, Wong ET, Eichler A, Schiff D, Groves MD, Mikkelsen T, Rosenfeld S, Sarantopoulos J, Meyers CA, Fielding RM, Elian K, Wang X, Lawrence B, Shing M, Kelsey S, Castaigne JP, Wen PY. 
Phase I Study of GRN1005 in Recurrent Malignant Glioma. Clin Cancer Res 2013;19:1567-76.

33. Jones AR, Shusta EV. Blood-brain barrier transport of therapeutics via receptor-mediation. Pharm Res 2007;24:1759-71.

34. Rip J, Schenk GJ, de Boer AG. Differential receptor-mediated drug targeting to the diseased brain. Expert Opin Drug Deliv 2009;6:227-37.

35. Wang YY, Lui PC, Li JY. Receptor-mediated therapeutic transport across the blood-brain barrier. Immunotherapy 2009;1:983-93.

36. Papademetriou LT, Porter T. Promising approaches to circumvent the blood-brain barrier: progress, pitfalls and clinical prospects in brain cancer. Ther Deliv 2015;6:989-1016.

37. Demeule M, Regina A, Che C, Poirier J, Nguyen T, Gabathuler R, Castaigne JP, Beliveau R. Identification and design of peptides as a new drug delivery system for the brain. J Pharmacol Exp Ther 2008;324:1064-72.

38. Jefferies W. CNS-targeted conjugates having modified fe regions and methods of use thereof. In: Bioasis Technologies Inc.; 2015. (ISBN No. US20150093399 A1)

39. Demeule M, Currie JC, Bertrand Y, Che C, Nguyen T, Regina A, Gabathuler R, Castaigne JP, Beliveau R. Involvement of the low-density lipoprotein receptor-related protein in the transcytosis of the brain delivery vector angiopep-2. J Neurochem 2008;106:1534-44.

40. Kurzrock R, Gabrail N, Chandhasin C, Moulder S, Smith C, Brenner A, Sankhala K, Mita A, Elian K, Bouchard D, Sarantopoulos J. Safety, pharmacokinetics, and activity of GRN1005, a novel conjugate of angiopep-2, a peptide facilitating brain penetration, and paclitaxel, in patients with advanced solid tumors. Mol Cancer Ther 2012;11:308-16.

41. Menlo Park C. Geron Discontinues GRN1005 and Restructures to Focus on Imetelstat Development in Hematologic Malignancies and Solid Tumors with Short Telomeres. In; 2012.

42. Che C, Yang G, Thiot C, Lacoste MC, Currie JC, Demeule M, Regina A, Beliveau R, Castaigne JP. New Angiopep-modified doxorubicin (ANG1007) and etoposide (ANG1009) chemotherapeutics with increased brain penetration. J Med Chem 2010;53:2814-24.

43. Bertrand Y, Currie JC, Demeule M, Regina A, Che C, Abulrob A, Fatehi D, Sartelet H, Gabathuler R, Castaigne JP, Stanimirovic D, Beliveau R. Transport characteristics of a novel peptide platform for CNS therapeutics. J Cell Mol Med 2010;14:2827-39.

44. Thomas FC, Taskar K, Rudraraju V, Goda S, Thorsheim HR, Gaasch JA, Mittapalli RK, Palmieri D, Steeg PS, Lockman PR, Smith QR. Uptake of ANG1005, a novel paclitaxel derivative, through the blood-brain barrier into brain and experimental brain metastases of breast cancer. Pharm Res 2009;26:2486-94.

45. Xin H, Jiang X, Gu J, Sha X, Chen L, Law K, Chen Y, Wang X, Jiang Y, Fang X. Angiopep-conjugated poly(ethylene glycol)-co-poly(epsiloncaprolactone) nanoparticles as dual-targeting drug delivery system for brain glioma. Biomaterials 2011;32:4293-305.

46. Shen J, Zhan C, Xie C, Meng Q, Gu B, Li C, Zhang Y, Lu W. Poly (ethylene glycol)-block-poly(D, L-lactide acid) micelles anchored with angiopep-2 for brain-targeting delivery. J Drug Target 2011;19:197-203.

47. Sun X, Pang Z, Ye H, Qiu B, Guo L, Li J, Ren J, Qian Y, Zhang Q, Chen J, Jiang X. Co-delivery of pEGFP-hTRAIL and paclitaxel to brain glioma mediated by an angiopep-conjugated liposome. Biomaterials 2012;33:916-24.

48. Gaillard PJ. Conjugates for targeted drug delivery across the blood-brain barrier. In: to-BBB Holding B.V.; 2013. (ISBN No. EP2308514 B1)

49. Gaillard PJ, De Boer AG, Brink A. Differentially Expressed Nucleic Acids in the Blood-Brain Barrier Under Inflammatory Conditions. In: Gaillard, P.J.De Boer, A.G. Brink, A.; 2008. (ISBN No. US20080213179 A1)

50. Gaillard PJ. Glutathione-based drug delivery system. In: To-Bbb Holding B.V.; 2010. (ISBN No. WO2010095940 A2)

51. Dickerson IM, Brown EB. Methods of treating cancer using an agent that modulates activity of the calcitonin-gene related peptide ("CGRP") receptor. In: University Of Rochester; 2011. (ISBN No. US 20110189205 A1)

52. Furness S, Johns T, Wookey PJ. Diagnosis and treatment of brain tumors. In: Welcome Receptor Antibodies Pty Ltd; 2012. (ISBN No.
WO2012000062 A1)

53. Tortorella S, Karagiannis TC. Transferrin receptor-mediated endocytosis: a useful target for cancer therapy. J Membr Biol 2014;247:291-307.

54. Ding H, Ljubimova JY, Holler E, Black KL. Poly (beta malic acid) with pendant Leu-Leu-Leu tripeptide for effective cytoplasmic drug delivery. In: Cedars-Sinai Medical Center; 2014. (ISBN No. US 8795648 B2)

55. Patil R, Holler E, Black KL, Ljubimova JY. Drug delivery of temozolomide for systemic based treatment of cancer. In: Cedars-Sinai Medical Center; 2014. (ISBN No. US20140161762 A1)

56. Weiss N, Miller F, Cazaubon S, Couraud PO. [Blood-brain barrier part III: therapeutic approaches to cross the blood-brain barrier and target the brain]. Rev Neurol 2010;166:284-8.

57. Estella-Hermoso de Mendoza A, Preat V, Mollinedo F, Blanco-Prieto MJ. In vitro and in vivo efficacy of edelfosine-loaded lipid nanoparticles against glioma. J Control Release 2011;156:421-6.

58. Coley HM. Overcoming multidrug resistance in cancer: clinical studies of p-glycoprotein inhibitors. Methods Mol Biol 2010;596:341-58.

59. Das M, Sahoo SK. Folate decorated dual drug loaded nanoparticle: role of curcumin in enhancing therapeutic potential of nutlin-3a by reversing multidrug resistance. PLoS One 2012;7:e32920.

60. Kim MK, Choo H, Chong Y. Water-soluble and cleavable quercetin-amino acid conjugates as safe modulators for P-glycoprotein-based multidrug resistance. J Med Chem 2014;57:7216-33.

61. Kim MK, Park KS, Choo H, Chong Y. Quercetin-POM (pivaloxymethyl) conjugates: Modulatory activity for P-glycoprotein-based multidrug resistance. Phytomedicine 2015;22:778-85.

62. Romiti N, Tramonti G, Donati A, Chieli E. Effects of grapefruit juice on the multidrug transporter P-glycoprotein in the human proximal tubular cell line HK-2. Life Sci 2004;76:293-302.

63. Banks WA, Kumar VB, Darling T, Clayton R. Modulation of blood-brain barrier protein expression. In: St. Louis University; 2010. (ISBN No. US20100196393 A1)

64. McChesney JD, Tapolsky G, Emerson DL, Marshall J, Ahmed T, Cohn A, Kurman M, Modiano M. Taxane analogs for the treatment of brain cancer. In: Tapestry Pharmaceuticals, Inc.; 2011. (ISBN No. US 20110318334 A1)

65. Tosi G, Vergoni AV, Ruozi B, Bondioli L, Badiali L, Rivasi F, Costantino L, Forni F, Vandelli MA. Sialic acid and glycopeptides conjugated PLGA nanoparticles for central nervous system targeting: In vivo pharmacological evidence and biodistribution. J Control Release 2010;145:49-57.

66. Bazile D, Prud'homme C, Bassoullet MT, Marlard M, Spenlehauer G, Veillard M. Stealth Me. PEG-PLA nanoparticles avoid uptake by the mononuclear phagocytes system. J Pharm Sci 1995;84:493-8.

67. Niidome T, Yamagata M, Okamoto Y, Akiyama Y, Takahashi H, Kawano T, Katayama Y, Niidome Y. PEG-modified gold nanorods with a stealth character for in vivo applications. J Control Release 2006;114:343-7.

68. Weissenbock A, Wirth M, Gabor F. WGA-grafted PLGA-nanospheres: preparation and association with Caco-2 single cells. $J$ Control Release 2004;99:383-92

69. Brigger I, Dubernet C, Couvreur P. Nanoparticles in cancer therapy and diagnosis. Adv Drug Deliv Rev 2002;54:631-51.

70. Zhang P, Ling G, Sun J, Zhang T, Yuan Y, Sun Y, Wang Z, He Z. Multifunctional nanoassemblies for vincristine sulfate delivery to overcome multidrug resistance by escaping P-glycoprotein mediated efflux. Biomaterials 2011;32:5524-33.

71. Petkar KC, Chavhan SS, Agatonovik-Kustrin S, Sawant KK. Nanostructured materials in drug and gene delivery: a review of the state of the art. Crit Rev Ther Drug Carrier Syst 2011;28:101-64.

72. Meyers JD, Doane T, Burda C, Basilion JP. Nanoparticles for imaging and treating brain cancer. Nanomedicine 2013;8:123-43.

73. Chen Y, Liu L. Modern methods for delivery of drugs across the bloodbrain barrier. Adv Drug Deliv Rev 2012;64:640-65.

74. De Jong WH, Borm PJ. Drug delivery and nanoparticles: applications and hazards. Int J Nanomedicine 2008;3:133.

75. Garcia-Garcia E, Andrieux K, Gil S, Couvreur P. Colloidal carriers and blood-brain barrier (BBB) translocation: a way to deliver drugs to the 
brain? Int J Pharm 2005;298:274-92.

76. Wesselinova D. Current major cancer targets for nanoparticle systems. Curr Cancer Drug Targets 2011;11:164-83.

77. Adams ML, Lavasanifar A, Kwon GS. Amphiphilic block copolymers for drug delivery. J Pharm Sci 2003;92:1343-55.

78. Li AJ, Zheng YH, Liu GD, Liu WS, Cao PC, Bu ZF. Efficient delivery of docetaxel for the treatment of brain tumors by cyclic RGD-tagged polymeric micelles. Mol Med Rep 2015;11:3078-86.

79. Krebs MD. Biodegradable polymers for delivery of therapeutic agents. In: Colorado School Of Mines; 2014. (ISBN No. US20140377366 A1)

80. Bae YH, Na K, Lee ES. PH-sensitive polymeric micelles for drug delivery. In: University Of Utah Research Foundation; 2010. (ISBN No. US 7659314 B2)

81. Zhou Z, Patel TR, Piepmeier JM, Saltzman WM. Highly penetrative nanocarriers for treatment of cns disease. In: Yale University; 2015. (ISBN No. US20150118311 A1)

82. Wu XY, Shalviri A. Polymeric nanoparticles useful in theranostics. In: The Governing Council Of The University Of Toronto; 2013. (ISBN No. WO2013127004 A1)

83. Yerushalmi N, Kredo-Russo S, Lithwick YG, Satchi-Fainaro R, Ofek P. Nanocarrier system for micrornas and uses thereof. In: Rosetta Genomics Ltd. and Ramot At Tel-Aviv University Ltd; 2014. (ISBN No. WO2014203189 A1)

84. Tour JM, Berlin J, Marcano D, Baskin DS, Sharpe MA. Targeted nanovectors and their use for treatment of brain tumors. In: The Methodist Hospital Research Institute \& William Marsh Rice University; 2014. (ISBN No. US 20140154269 A1)

85. Muller LK, Landfester K. Natural liposomes and synthetic polymeric structures for biomedical applications. Biochem Biophys Res Commun 2015;468:411-8.

86. Lai F, Fadda AM, Sinico C. Liposomes for brain delivery. Expert Opinion on Drug Delivery 2013;10:1003-22.

87. Xiang Y, Liang L, Wang X, Wang J, Zhang X, Zhang Q. Chloride channelmediated brain glioma targeting of chlorotoxin-modified doxorubicineloaded liposomes. J Control Release 2011;152:402-10.

88. Li XY, Zhao Y, Sun MG, Shi JF, Ju RJ, Zhang CX, Li XT, Zhao WY, Mu LM, Zeng F, Lou JN, Lu WL. Multifunctional liposomes loaded with paclitaxel and artemether for treatment of invasive brain glioma. Biomaterials 2014;35:5591-604.

89. Chen H, Qin Y, Zhang Q, Jiang W, Tang L, Liu J, He Q. Lactoferrin modified doxorubicin-loaded procationic liposomes for the treatment of gliomas. Eur J Pharm Sci 2011;44:164-73.

90. Migliore MM, Vyas TK, Campbell RB, Amiji MM, Waszczak BL. Brain delivery of proteins by the intranasal route of administration: a comparison of cationic liposomes versus aqueous solution formulations. J Pharm Sci 2010;99:1745-61.

91. Munson JM, Bellamkonda RV, Arbiser JL. Nanocarrier therapy for treating invasive tumors. In: Emory University \& Georgia Institute Of Technology; 2010. (ISBN No. WO2010124004 A2)

92. Redelmeier T, Luz M. Liposomal Composition for Convection-Enhanced Delivery to the Central Nervous system. In: MedGenesis Therapeutix Inc.; 2011. (ISBN No. US20110274625 A1)

93. Mehnert W, Mader K. Solid lipid nanoparticles: production, characterization and applications. Adv Drug Deliv Rev 2001;47:165-96.

94. Kaur IP, Bhandari R, Bhandari S, Kakkar V. Potential of solid lipid nanoparticles in brain targeting. J Control Release 2008;127:97-109.

95. Panyam J, Chavanpatil MD. Lipid-derived nanoparticles for brain-targeted drug delivery. In: Panyam, J. and Chavanpatil, M. D.; 2010. (ISBN No. US 20100076092 A1)

96. Jin J, Bae KH, Yang H, Lee SJ, Kim H, Kim Y, Joo KM, Seo SW, Park TG, Nam DH. In vivo specific delivery of c-Met siRNA to glioblastoma using cationic solid lipid nanoparticles. Bioconjug Chem 2011;22:2568-72.

97. Singh I, Swami R, Pooja D, Jeengar MK, Khan W, Sistla R. Lactoferrin bioconjugated solid lipid nanoparticles: a new drug delivery system for potential brain targeting. J Drug Target 2016 24:212-23
98. Minotti G, Menna P, Salvatorelli E, Cairo G, Gianni L. Anthracyclines: molecular advances and pharmacologic developments in antitumor activity and cardiotoxicity. Pharmacol Rev 2004;56:185-229.

99. Gaillard PJ, Appeldoorn CCM, Dorland R, van Kregten J, Manca F, Vugts DJ, Windhorst B, van Dongen GAMS, de Vries HE, Maussang D, van Tellingen O. Pharmacokinetics, Brain Delivery, and Efficacy in Brain Tumor-Bearing Mice of Glutathione Pegylated Liposomal Doxorubicin (2B3-101). PLoS One 2014;9:e82331.

100. Gaillard PJ, Kerklaan BM, Aftimos P, Altintas S, Jager A, Gladdines W, Lonnqvist F, Soetekouw P, Verheul H, Awada A, Schellens J, Brandsma D. Abstract CT216: Phase I dose escalating study of 2B3-101, glutathione PEGylated liposomal doxorubicin, in patients with solid tumors and brain metastases or recurrent malignant glioma. Cancer Res 2014;74:CT216.

101. Nektar Therapeutics. Etirinotecan Pegol (NKTR-102): A Next-Generation Topoisomerase I Inhibitor Being Developed in Breast, Ovarian and Colorectal Cancers. In. Etirinotecan Pegol (NKTR-102). USA: "Nektar Therapeutics"; 2013.

102. Nagpal S, Recht CK, Bertrand S, Thomas RP, Ajlan A, Pena J, Gershon M, Coffey G, Kunz PL, Li G, Recht LD. Phase II pilot study of singleagent etirinotecan pegol (NKTR-102) in bevacizumab-resistant high grade glioma. Neuro Oncol 2015;123:277-82.

103. Hermanson GT. Chapter 1 - Introduction to Bioconjugation. In: editor editors, editor. Bioconjugate Techniques. Boston:Academic Press;2013.p.1-125.

104. Duncan R. Polymer conjugates as anticancer nanomedicines. Nat Rev Cancer 2006;6:688-701.

105. Bacha JA, Brown D, Dunn S, Steinø A. Use of dianhydrogalactitol and analogs and derivatives thereof to treat glioblastoma multiforme. In: Del Mar Pharmaceuticals; 2014. (ISBN No. US20140221442 A1)

106. Tschoepe M, Kaleta K, Kumar V. Anti-egfr antibody drug conjugate formulations. In: Abbvie Deutschland Gmbh \& Co.Kg, Abbvie Inc.; 2014. (ISBN No. WO2014143765 A1)

107. Adair JH, Kester M, Smith JP, Altinoglu EI, Barth BM, Kaiser JM, Matters GL, Mcgovern C, Morgan TT, Sharma R. Bioconjugation of calcium phosphosilicate nanoparticles for selective targeting of cells in vivo. In: The Pennsylvania State Research Foundation; 2011. (ISBN No. WO 2011057216 A1)

108. Hutchison R, Vitalis TZ, Gabathuler R. P97-antibody conjugates and methods of use. In: Bioasis Technologies, Inc.; 2013. (ISBN No. US 20130183368 A1)

109. Kang T, Jiang M, Jiang D, Feng X, Yao J, Song Q, Chen H, Gao X, Chen J. Enhancing Glioblastoma-Specific Penetration by Functionalization of Nanoparticles with an Iron-Mimic Peptide Targeting Transferrin/ Transferrin Receptor Complex. Mol Pharm 2015;12:2947-61.

110. Dardevet L, Rani D, Aziz TA, Bazin I, Sabatier JM, Fadl M, Brambilla E, De Waard M. Chlorotoxin: a helpful natural scorpion peptide to diagnose glioma and fight tumor invasion. Toxins (Basel) 2015;7:1079-101.

111. Pyrko P, Wang W, Markland FS, Swenson SD, Schmitmeier S, Schonthal $\mathrm{AH}$, Chen TC. The role of contortrostatin, a snake venom disintegrin, in the inhibition of tumor progression and prolongation of survival in a rodent glioma model. J Neurosurg 2005;103:526-37.

112. Kasai T, Nakamura K, Vaidyanath A, Chen L, Sekhar S, El-Ghlban S, Okada M, Mizutani A, Kudoh T, Murakami H, Seno M. Chlorotoxin Fused to IgG-Fc Inhibits Glioblastoma Cell Motility via ReceptorMediated Endocytosis. J Drug Deliv 2012;2012:975763.

113. Yoo B, Ifediba MA, Ghosh S, Medarova Z, Moore A. Combination treatment with theranostic nanoparticles for glioblastoma sensitization to TMZ. Mol Imaging Biol 2014;16:680-9.

114. Locatelli E, Naddaka M, Uboldi C, Loudos G, Fragogeorgi E, Molinari V, Pucci A, Tsotakos T, Psimadas D, Ponti J, Franchini MC. Targeted delivery of silver nanoparticles and alisertib: in vitro and in vivo synergistic effect against glioblastoma. Nanomedicine (Lond) 2014;9:839-49.

115. Zhao L, Zhu J, Cheng Y, Xiong Z, Tang Y, Guo L, Shi X, Zhao J. Chlorotoxin-Conjugated Multifunctional Dendrimers Labeled with Radionuclide 131I for Single Photon Emission Computed Tomography 
Imaging and Radiotherapy of Gliomas. ACS Appl Mater Interfaces 2015; 7:19798-808.

116. Zhao L, Shi X, Zhao J. Chlorotoxin-conjugated nanoparticles for targeted imaging and therapy of glioma. Curr Top Med Chem 2015;15:1196-208.

117. Wang X, Guo Z. Chlorotoxin-conjugated onconase as a potential antiglioma drug. Oncol Lett 2015;9:1337-42.

118. Wang H, Gu W, Xiao N, Ye L, Xu Q. Chlorotoxin-conjugated graphene oxide for targeted delivery of an anticancer drug. Int $J$ Nanomedicine 2014;9:1433-42.

119. Cheng Y, Zhao J, Qiao W, Chen K. Recent advances in diagnosis and treatment of gliomas using chlorotoxin-based bioconjugates. Am J Nucl Med Mol Imaging 2014;4:385-405.

120. Zhang M, Ellenbogen RG, Kievit F, Silber JR, Stephen Z, Veiseh O. Nanoparticle for targeting brain tumors and delivery of o6-benzylguanine. In: University of Washington through its Center for Commercialization; 2014. (ISBN No. US20140286872 A1)

121. Veiseh O, Kievit FM, Fang C, Mu N, Jana S, Leung MC, Mok H, Ellenbogen RG, Park JO, Zhang M. Chlorotoxin bound magnetic nanovector tailored for cancer cell targeting, imaging, and siRNA delivery. Biomaterials 2010;31:8032-42.

122. Kievit FM, Veiseh O, Fang C, Bhattarai N, Lee D, Ellenbogen RG, Zhang M. Chlorotoxin labeled magnetic nanovectors for targeted gene delivery to glioma. ACS Nano 2010;4:4587-94.

123. Butte PV, Mamelak A, Parrish-Novak J, Drazin D, Shweikeh F, Gangalum PR, Chesnokova A, Ljubimova JY, Black K. Near-infrared imaging of brain tumors using the Tumor Paint BLZ-100 to achieve near-complete resection of brain tumors. Neurosurg Focus 2014;36:E1.

124. Fidel J, Kennedy KC, Dernell WS, Hansen S, Wiss V, Stroud MR, Molho JI, Knoblaugh SE, Meganck J, Olson JM, Rice B, ParrishNovak J. Preclinical Validation of the Utility of BLZ-100 in Providing Fluorescence Contrast for Imaging Spontaneous Solid Tumors. Cancer Res 2015;75:4283-91.

125. Rodriguez-Devora JI, Ambure S, Shi Z-D, Yuan Y, Sun W, Xu T. Physically facilitating drug-delivery systems. Ther Deliv 2012;3:125-39.

126. Davalos RV, Rossmeisl JH, Garcia PA. Acute blood-brain barrier disruption using electrical energy based therapy. In: Virginia Tech Intellectual Properties, Inc.; 2014. (ISBN No. US20140039489A1)

127. Qiu LB, Ding GR, Li KC, Wang XW, Zhou Y, Zhou YC, Li YR, Guo GZ. The role of protein kinase $\mathrm{C}$ in the opening of blood-brain barrier induced by electromagnetic pulse. Toxicology 2010;273:29-34.

128. Braun S, Oppermann H, Mueller A, Renner C, Hovhannisyan A, BaranSchmidt R, Gebhardt R, Hipkiss A, Thiery J, Meixensberger J, Gaunitz F. Hedgehog signaling in glioblastoma multiforme. Cancer Biol Ther 2012;13:487-95.

129. Akhtari M, Engel J. Use of functionalized magnetic nanoparticles in cancer detection and treatment. In: The Regents Of The University Of California; 2015. (ISBN No. US 9011913 B2)

130. Yang VC, David AE. Compositions and methods for targeting tumors. In: The Regents Of The University Of Michigan; 2011. (ISBN No. US20110054236 A1)

131. Dixit S, Miller K, Zhu Y, McKinnon E, Novak T, Kenney ME, Broome AM. Dual Receptor-Targeted Theranostic Nanoparticles for Localized Delivery and Activation of Photodynamic Therapy Drug in Glioblastomas. Mol Pharm 2015;12:3250-60.

132. Liu H-L, Fan C-H, Ting C-Y, Yeh C-K. Combining Microbubbles and Ultrasound for Drug Delivery to Brain Tumors: Current Progress and Overview. Theranostics 2014;4:432-44.

133. Hynynen K, McDannold N, Sheikov NA, Jolesz FA, Vykhodtseva N. Local and reversible blood-brain barrier disruption by noninvasive focused ultrasound at frequencies suitable for trans-skull sonications. Neuroimage 2005;24:12-20.

134. Blomley MJK, Cooke JC, Unger EC, Monaghan MJ, Cosgrove DO. Microbubble contrast agents: a new era in ultrasound. BMJ : British Medical Journal 2001;322:1222-5.

135. Kang ST, Yeh CK. Ultrasound microbubble contrast agents for diagnostic and therapeutic applications: current status and future design. Chang Gung Med J 2012;35:125-39.

136. Chen YC, Chiang CF, Wu SK, Chen LF, Hsieh WY, Lin WL. Targeting microbubbles-carrying TGFbetal inhibitor combined with ultrasound sonication induce $\mathrm{BBB} / \mathrm{BTB}$ disruption to enhance nanomedicine treatment for brain tumors. J Control Release 2015;211:53-62.

137. Liao AH, Chou HY, Hsieh YL, Hsu SC, Wei KC, Liu HL. Enhanced Therapeutic Epidermal Growth Factor Receptor (EGFR) Antibody Delivery via Pulsed Ultrasound with Targeting Microbubbles for Glioma Treatment. Journal of Medical and Biological Engineering 2015;35:156-64.

138. Bartel DP. MicroRNAs: genomics, biogenesis, mechanism, and function. Cell 2004;116:281-97.

139. Iwakawa HO, Tomari Y. The Functions of MicroRNAs: mRNA Decay and Translational Repression. Trends Cell Biol 201510.1016/j. tcb.2015.07.011.

140. Alvarez-Garcia I, Miska EA. MicroRNA functions in animal development and human disease. Development 2005; 132:4653-62.

141. LeBlanc VC, Morin P. Exploring miRNA-Associated Signatures with Diagnostic Relevance in Glioblastoma Multiforme and Breast Cancer Patients. J Clin Med 2015;4:1612-30.

142. Hummel R, Maurer J, Haier J. MicroRNAs in brain tumors : a new diagnostic and therapeutic perspective? Mol Neurobiol 2011;44:223-34.

143. Novakova J, Slaby O, Vyzula R, Michalek J. MicroRNA involvement in glioblastoma pathogenesis. Biochem Biophys Res Commun 2009;386:1-5.

144. Chan JA, Krichevsky AM, Kosik KS. MicroRNA-21 is an antiapoptotic factor in human glioblastoma cells. Cancer Res 2005;65:6029-33.

145. Møller HG, Rasmussen AP, Andersen HH, Johnsen KB, Henriksen M, Duroux M. A Systematic Review of MicroRNA in Glioblastoma Multiforme: Micro-modulators in the Mesenchymal Mode of Migration and Invasion. Molecular Neurobiology 2013;47:131-44.

146. Park JB, Lee SH, Park EK, Lee D, Yang HS, Yoo H, Kim HJ, Kim TH, Kwak HJ. Anti-cancer composition comprising microrna molecules. In: National Cancer Center; 2011. (ISBN No. US20110124712 A1)

147. Keefe AD, Pai S, Ellington A. Aptamers as therapeutics. Nat Rev Drug Discov 2010;9:537-50.

148. Rich JN, Kim Y, Hjelmeland A. Aptamers for tumor initiating cells. In: The Cleveland Clinic Foundation; 2014. (ISBN No. WO2014121256 A1)

149. Bloembergen S, McLennan IJ, Jones N, Wagner R, Shermon AKG, Elsayed AR, Liu J. Aptamer bioconjugate drug delivery device. In: Ecosynthetix Ltd.; 2013. (ISBN No. US 20130090467 A1)

150. Jatariu A, Peptu C, Popa M, Indrei A. Micro- and nanoparticles--medical applications. Rev Med Chir Soc Med Nat Iasi 2009;113:1160-9.

151. Burgess R. Medical applications of nanoparticles and nanomaterials. Stud Health Technol Inform 2009;149:257-83.

152. Irache JM. [Nanomedicine: nanoparticles with medical applications]. An Sist Sanit Navar 2008;31:7-10.

153. Dusinska M, Dusinska M, Fjellsbo L, Magdolenova Z, Rinna A, Runden Pran E, Bartonova A, Heimstad E, Harju M, Tran L, Ross B, Juillerat L, Halamoda Kenzaui B, Marano F, Boland S, Guadaginini R, Saunders M, Cartwright L, Carreira S, Whelan M, Kelin C, Worth A, Palosaari T, Burello E, Housiadas C, Pilou M, Volkovova K, Tulinska J, Kazimirova A, Barancokova M, Sebekova K, Hurbankova M, Kovacikova Z, Knudsen L, Poulsen M, Mose T, Vila M, Gombau L, Fernandez B, Castell J, Marcomini A, Pojana G, Bilanicova D, Vallotto D. Testing strategies for the safety of nanoparticles used in medical applications. Nanomedicine 2009;4:605-7.

154. to-BBB technologies BV. Company restarting as 2-BBB Medicines BV. In. The Netherlands; 2015.

155. TEDxMaastricht. Brain Train. Effective Brain Cancer Treatment: Pieter Gaillard at TEDxMaastricht. In: TEDxMaastricht, editor: Gaillard, P.; 2013.

156. Lammers T, Hennink WE, Storm G. Tumour-targeted nanomedicines: principles and practice. Br J Cancer 2008;99:392-7. 